\title{
The Relationship between Upholding Taihang Spirit and Carrying Forward the Party's Mass Line
}

\author{
Yanping Dou ${ }^{1}$ \\ ${ }^{1}$ School of Humanities, Economics and Law, \\ Northwestern Polytechnical University, \\ Xi'an 710072, PR China
}

\author{
Zhikai Yun ${ }^{1}$ \\ ${ }^{1}$ School of Humanities, Economics and Law, \\ Northwestern Polytechnical University, \\ Xi'an 710072, PR China
}

\begin{abstract}
Upholding Taihang spirit goes in consistency with carrying forward the Party's mass line. We should fully comprehend and consciously put into use the essence of the profound theory of Taihang Spirit for the purpose of translating the red cultural advantages of Taihang Spirit, namely "Firmness, Solidness, Thickness and Heaviness" into the developmental advantages for carrying forward the Party's mass line and accelerating the economic and social transformation. We should carry out the educational practice of the Party's mass line and continuously improve the scientific level of Party building.
\end{abstract}

Keywords: Taihang Spirit, The Party's mass line, Relationship

\section{INTRODUCTION}

Chinese Communist Party (CPC) has gone through 93 years' glorious history. In the past years, the Party and people of all Chinese ethnic groups have won major victories one after another in revolution, country building and economic reform with their concerted and tenacious efforts. Consequently, a vibrant and uprising new socialist China now stands firmly in the east of the world. After the successful convening the 18th National Congress of CPC, 1.3 billion Chinese people with full confidence are on their way to the great rejuvenation of the Chinese nation under the banner of socialism with Chinese characteristics. However, the whole Party must be soberly aware that under the new circumstances that the situation of the world, the country and the Party is undergoing profound changes, the Party has to improve its leadership and governance, strengthen the ability of resisting corruption and risks, advance the construction of ruling ability and performance, and deal with unprecedented new problems and challenges. The test from governance, opening up and reform, market economy and external environment is long-term, complicated and austere. The danger of laxity in mind, insufficient ability, divorce from mass, negativity and corruption is confronting more severely the Party than before, which requires the Party to manage and discipline itself in a more strict and urgent manner. Therefore, we need to start from the new situation, adhere to the scientific theory to guide the Party building, and study and solve the major theoretical and practical issues facing the Party in the spirit of reform and innovation. [1]

In his important speech, Xi Jinping, General Secretary of the Party pointed out that we should fully acknowledge the extreme importance and imperativeness of carrying forward the Party's mass line, intensify the political, crisis and responsibility awareness of the Party, and carry out all work related to the Party's mass line. His remarks reflect the important direction of the Party under new circumstances and illustrate that it is imperative to carry forward the Party's mass line.

Shanxi's "collapse mode of corruption" told us that upholding Taihang Spirit is in consistency with carrying forward the Party's mass line. Taihang Spirit embodies the ceaseless innovation and exploration spirit upheld by the Party and the Chinese people and the military to fight against the Japanese invaders under the leadership of the Party. It is also the vivid manifestation of the Party's ideological line of seeking truth from facts, and the important fruit of yielded by combining the Marxism and Leninism, Mao Zedong's thought with the specific revolutionary practice of China. Besides, it fully indicates that the CPC is the core leadership to deliver and to revitalize the Chinese nation, and also the faithful representative of the fundamental interest of the majority people. Taihang Spirit is the embodiment of the heroism of Taihang people and proves that the Chinese nation is an invincible great nation. Inspired by it, we have won the victory of revolutionary struggle; at present and in the future, motivated by it, we will surely achieve the new victory of socialist modernization construction. Therefore, we should strengthen the Party building and stick to the Party's mass line. Specifically, on the land of Shanxi, we should give full play to the advantages of thinking and cultural resources in this province and vigorously promote Taihang Spirit of "Firmness, Solidness, Thickness and Heaviness". We should fully comprehend and consciously put into use the essence of the profound theory of Taihang Spirit for the purpose of carrying out the educational practice of the Party's mass line, promoting in a 
comprehensive way the new grand project of Party building and enhancing continuously the scientific level of Party building.

\section{The Relationship between Taihang Spirit and Carrying Forward the Party's mass line}

\subsection{Taihang Spirit and adhering to the Party's mass line are both magic keys to deal with all sorts of difficulties and challenges}

During eight-year-long anti-Japanese war, the Eighth Route Army fought a bloody war in the lofty Taihang Mountains. With their lives, blood and iron-will to fight, and especially under the support of the local people, they took advantage of favorable terrain to carry out the desperate fight against the Japanese invaders. Such exceedingly difficult, complex, tortuous and dangerous struggle environment incubated a large number of talents with excellent capabilities of managing the Party, the country or the military and the valuable Taihang Spirit, who are the solid foundation for the victory of anti-Japanese war and China's revolution. Taihang Mountains fed China's revolution, cradled the Eighth Route Army, and gave life to the Taihang Spirit of the great Chinese nation centered by anti-invaders. [2]

Taihang Spirit is the accumulation and continuation of Chinese national spirit of thousands of years. It is by this spirit that the Party led the whole nation in driving out the Japanese invaders and fully supporting the liberation war. By this spirit, the Party and the whole nation work hard to carry out the modernization construction of the socialism and make enormous changes to the previously poor and backward China. Obviously, Taihang Spirit is the Holy Grail to defeat enemies in war time and also the magic key to get rid of poverty and create wealth in the period of reform and opening up. As long as we keep Taihang Spirit of "Firmness, Solidness, Thickness and Heaviness", we will overcome whatever difficult we encounter and go ahead invincibly.

Since the opening of the 18th National Congress of CPC, the Central Committee of CPC, with $\mathrm{Xi}$ Jinping as the General Secretary, proposed the strategic arrangement of "Four Comprehensiveness", namely, to build China into a comprehensively well-off society, to comprehensively deepen reform, to rule the country by law comprehensively and to maintain Party discipline strictly and comprehensively. At the very time that China is in the crucial period of building up a comprehensively well-off society and deepening reform and opening up and at the critical moment of accelerating the transformation of economic development mode, the Party is facing more severe test than ever before from ruling the country, opening and reform, market economy and external environment, and more prominent dangers of laxity in mind, insufficient ability, divorce from mass, negativity and corruption. Adhering to the Party's mass line is the key to cope with and withstand all sorts of tests and to overcome all kinds of dangers in the course of reform and opening up and constructing socialism modernization. Presently, the Party as a whole is pure, united and battle tough, which is the fundamental guarantee for continuous achievement in China's socialist course. However, in the wake of profound changes occurring in domestic and international environment, it becomes more and more onerous to manage the Party and the Party's mass line is facing new situations and some new problems.

Adhering to the Party's mass line is the significant political requirement proposed by the Central Committee of the Party for the sake of developing the Party's advanced nature and the construction of the Marxist ruling party. It is also the urgent and important task for the Party to better counter risks and challenges from the point of its realistic construction. When the reform and opening is deepening, the market economy is advancing, and the ruling Party is growing bigger and stronger, Xi Jinping, General Secretary, pointed out that we should be fully aware of the extreme significance and urgency of adhering to the Party's mass line, enhance our political awareness, crisis awareness, responsibility awareness and carry out well the educational practice of the Party's mass line. Upholding the Party's mass line has become an increasingly important key to cultivate the advanced nature of the Party and to overcome crisis and difficulties, which requires the whole Party to pay arduous efforts.

\subsection{The fundamental value orientation of promoting Taihang Spirit and Upholding the Party's mass line is in the interest of Chinese nation and people}

People and army is the root for victory. In the anti-Japanese war, soldier and people at the base area made unremitting effort to fight against the Japanese invaders and the national cohesion was united unprecedentedly. What accounts this is that the anti-Japanese war policy pursued by the CPC and the CPC-led Eighth Route Army represents the supreme interest of the nation and the people. The Party's guiding ideology of actively resisting enemies encouraged, motivated, mobilized and organized extensive patriotic soldiers and people who hence saw hope in despair, awakened and rose up from humiliation, got together and united from the splintered moment and joined the battle against the Japanese invaders. This explains the unity of soldiers and people and why Chinese military army is also called the People's Liberation Army. Upholding the Party's mass line is the way to maintain the fresh and blood bondage between the Party and the people and to draw experiences, wisdom and strength from the practice of people. To improve and strengthen the working philosophy the Party, to carry forward the fine traditions of the Party, and to maintain the purity of the Party, the Party needs to keep close contact with people, keep in mind the approach of mass line, to gain from people wisdom and strength, to face straightly problems and difficulties, to skillfully 
resolve problems and conflicts, and to help people with their difficulties. To actively explore the good way of going deep into the people, the Party should take the initiative of taking care of the people emotionally and in action, experience their lives, understand their feelings, happiness and bitterness, take serving the people as the ultimate goal, unswervingly think as people think, hope as people hope, request as people request, mind our own duties whole heartedly, seek benefits for people, serve them in every way to improve their livelihood, living conditions and quality. [3]

In the course of constructing socialism with Chinese characteristics, we should continuously reinforce the education concerning the Party's purpose and the mass line, guide the party members and cadres to firmly serve the public and govern for the people, stick to the Marxist view of the people, and take whether the majority people's benefits have been maintained, realized and promoted as the standard to test the purity of the Party's philosophy, do the job well to make propaganda among the people, organize the people, serve the people, unite the people and lead the people to advance, and resolutely oppose any sign of divorce from people and showing indifference to people's difficulties.

\subsection{Promoting Taihang Spirit and adhering to the Party's mass line must abide by strict discipline}

Strict discipline is a powerful guarantee to maintain the Party's mass line. Leaders and cadres at all levels must enhance their sense of discipline, and translate the Party's disciplines in respect of politics, organization, economic work, mass and clean government into their own code of conduct. In particular, they should strictly observe political discipline, enhance political sensibility and discernment so as to unswervingly advocate the Party's leadership, follow the socialism path with Chinese characteristics without hesitation, firmly push forward reform and opening up, and keep highly consistent with the Central Committee of the Party. Leaders and cadres at all levels should shoulder the responsibility of intensifying discipline construction, severely punish disciplinary offences, including all kinds of corruption cases, make sure that everyone is equal before discipline and there is no privilege in observing discipline and no exception in enforcing discipline. As a consequence, the Party's discipline is truly the iron-like discipline that every party member must abide by it at any time under any circumstances. Party cadres are the subject of implementing discipline and their consciousness of enforcing discipline determines if the existing anti-corruption system has been put into place. [4]

Upholding the Party's mass line is the inevitable choice of our Party to counter risks, deal with challenges and withstand tests. We must take a strategic and overall perspective to view the close relationship between adhering to the Party's mass line and promoting Taihang Spirit, understand them as the condensed manifestation of the
Party's nature and aim, the pivotal to intensify the creativity, cohesion and battle competition of the Party, and the imperative measure to construct pure, clean and united Party leadership and cadres.

\section{Conclusion}

Carrying forward the Party's mass line is the inevitable requirement to strengthen Party building under new situations and also a major issue for Party leaders and cadres to strengthen self-building. Be a political party or individual party member, they should vigorously carry forward the national spirit and the spirit of times, carry out extensively education on patriotism, collectivism, and socialism, strengthen national self-esteem, self-confidence and pride, enhance the spirit of innovation, exploration and forging ahead and advance the establishment of moral civilization. They should insist on improving the social members' moral level by virtue of patriotism as reflected in the national spirit, intensify the awareness of "social interest" and "social ethics", stick to the lofty and pure pursuit of truth, kindness and beautifulness, develop the concept of public life and advocate civilized life style. [5] Only by doing so, the Party will have vigor and vitality, fighting capacity. As leaders and cadres of enterprises in Shanxi, we should continuously tap the spiritual wealth of Shanxi, maintain and uphold the Party's mass line. We should vigorously carry forward the Taihang Spirit of "Firmness, Solidness, Thickness and Heaviness", lift up the cadres and people's courage to overcome difficulties and strive for victory, encourage each other to work hard and serve the people. We should take the scientific concept of development as our guideline, stick to the forward direction of socialist advanced culture, translate the Taihang Spirit of "Firmness, Solidness, Thickness and Heaviness" into the developmental advantages of carrying forward the Party's mass line and accelerating the economic and social transformation, provide spiritual power for strengthening the Party building, urge all Party members to consciously safeguard the purity of the Party, and constantly improve the scientific level of Party building.

\section{References}

[1] Xi Jinping Party, "Speech at the Summary Conference of the Educational Practice of the Party's Mass Line," Studies in Dialectics of Nature, vol.10, 2014.

[2] Wang Yusheng, "Taihang Spirit," Beijing: People's Daily Press, 2011.

[3] Dou Yanping, "Taihang Spirit of Innovation and Development Is the Effective Medicine to Purify Current Political Environment of Shanxi," Vanguard, Vol.3, 2015.

[4] Dou Yanping, “Theoretical Reflections on Strengthening the Implementation of Anti-corruption Regime," Theoretical Exploration, vol.1, 2014. 
[5] Dou Yanping \& Yun Zhikai, "Taking the Chinese National Spirit as the Basis to Enhance Moral Construction for Virtue and Kindness," Journal of Northwestern Polytechnical University (Social Sciences), vol.4, 2014. 